\title{
Systems Level Neuroplasticity in Drug Addiction
}

\author{
Matthew W. Feltenstein and Ronald E. See \\ Department of Neurosciences, Medical University of South Carolina, Charleston, South Carolina 29425 \\ Correspondence: seere@musc.edu
}

Drug addiction is a chronic relapsing disorder for which research has been dedicated to understand the various factors that contribute to development, loss of control, and persistence of compulsive addictive behaviors. In this review, we provide a broad overview of various theories of addiction, drugs of abuse, and the neurobiology involved across the addiction cycle. Specific focus is devoted to the role of the mesolimbic pathway in acute drug reinforcement and occasional drug use, the mesocortical pathway and associated areas (e.g., the dorsal striatum) in escalation/dependence, and the involvement of these pathways and associated circuits in mediating conditioned responses, drug craving, and loss of behavioral control thought to underlie withdrawal and relapse. With a better understanding of the neurobiological factors that underlie drug addiction, continued preclinical and clinical research will aid in the development of novel therapeutic interventions that can serve as effective long-term treatment strategies for drug-dependent individuals.

$\mathrm{D}$ ug addiction is a chronic relapsing disorder characterized by compulsive drugseeking and drug-taking behaviors, loss of control in regulating intake, and the emergence of negative affect (e.g., dysphoria, anxiety) when access to the drug is withheld (Koob and Le Moal 1997; Koob and Volkow 2010). Accordingly, the American Psychiatric Association (American Psychiatric Association 1994) describes drug addiction (i.e., substance dependence) as a set of symptoms mainly involving the inability to reduce or control drug use. The recent National Survey on Drug Use and Health by the Substance Abuse and Mental Health Services Administration (SAMHSA 2011) estimates that 22.1 million Americans 12 years of age or older, or $8.7 \%$ of the population, have a substance abuse or dependence disorder. These es- timates include 2.9 million (1.1\%) classified as being dependent or abusing both alcohol and illicit drugs, 4.2 million (1.7\%) dependent or abusing of illicit drugs but not alcohol, and 15 million (5.9\%) as dependent or abusing of alcohol but not illicit drugs. Despite a gradual decrease in some types of addiction (e.g., nicotine dependence), the overall trend of substance abuse patterns has stabilized within the last decade, with evidence suggesting a high probability that an individual will relapse to drug taking following months or years of abstinence (Dackis and O'Brien 2001; Wagner and Anthony 2002). Given the detrimental societal and economic impact of substance abuse and addiction, significant research has been dedicated to understanding the neuropharmacological and neuroadaptive mechanisms that may mediate the

Editors: R. Christopher Pierce and Paul J. Kenny

Additional Perspectives on Addiction available at www.perspectivesinmedicine.org

Copyright (C) 2013 Cold Spring Harbor Laboratory Press; all rights reserved; doi: 10.1101/cshperspect.a011916

Cite this article as Cold Spring Harb Perspect Med 2013;3:a011916 
development and persistence of substance abuse disorders. In this chapter, we provide a brief overview of the theory, stages, and neurocircuitry that likely underlies the development of the addiction cycle (e.g., acute reinforcement/drug use, escalation/dependence, withdrawal/relapse).

\section{THEORIES AND STAGES OF ADDICTION}

Early theories suggested that addictive behaviors develop because of the pleasurable effect initially produced by a drug, with dependence occurring as a function of a recurrent drive for reward (Wise 1980). Although positive reinforcement is initially involved in the development of a substance abuse disorder, long-term drug abuse often results in the occurrence of aversive psychological and physiological effects if the drug is withheld, resulting in continued use as a means to avoid the aversive consequences of drug withdrawal (i.e., negative reinforcement) (Cami and Farre 2003). Thus, addictive behaviors likely include a gradual shift from positive reinforcement (impulsivity) to negative reinforcement (compulsivity) (Koob 2004). Although positive and negative reinforcement play a role in the initiation and maintenance of drug addiction behaviors, respectively, and thus may account for some aspects of the persistence of drug addiction (Wilker 1973), these conditioning theories cannot fully explain many aspects of drug dependence, such as the resumption of drug-seeking and drug-taking behaviors following a prolonged period of abstinence (i.e., relapse) when overt withdrawal symptoms have long dissipated. As such, a number of findings indicate that prolonged drug use leads to a series of neuroadaptations, thus contributing to the enduring nature of the addictive state.

Robinson and Berridge (Robinson and Berridge 1993; Berridge and Robinson 1995) postulated in their "incentive sensitization" theory of addiction that chronic exposure to drugs of abuse results in alterations in a number of neural systems, including areas normally involved in the motivation for natural appetitive rewards. As a result, the addict becomes hypersensitive to drug-associated stimuli (Clark and Overton 1998), leading to a shift from drug "liking" to "wanting," with ensuing compulsive patterns of drug-seeking behavior. In another perspective, Koob and Le Moal (1997, 2001) hypothesized that continuous drug use leads to a shift in an individual's hedonic set point and a state of dysregulation (including enhanced sensitivity and counteradaptation) of brain reward systems. As a result, the drug user's allostatic processes, or the ability to maintain stability or homeostasis through change, become disrupted, leading to a loss of control over drug intake and compulsive use. Other theories, including maladaptive associative learning (Di Chiara 1999; Hyman and Malenka 2001), loss of behavioral control and decision making because of altered prefrontal cortical activity (Jentsch and Taylor 1999; Franklin et al. 2002; Goldstein and Volkow 2002), and aberrant stimulus response learning resulting in the formation of engrained drug habits (Wise 2002; Everitt and Robbins 2005; Volkow et al. 2006), have centered on specific drug-induced neuroadaptations that may also play a role in the development and persistence of drug addiction. These theories collectively provide unique views on addiction, with overlap being noted among the different perspectives. However, given the multilayered complexity of addiction states and unique perspectives of each theory, it is not surprising that none can fully account for all aspects of the addictive cycle.

In general, drug addiction can be considered to consist of three stages: acute reinforcement/drug use, escalation/dependence, and withdrawal/relapse. However, whereas drug use does not necessarily result in the development of a drug dependence disorder (e.g., social smokers/drinkers), it should be noted that the acute reinforcing effects of many drugs of abuse have some predictive validity for the transition to later stages of the addiction cycle. Moreover, these stages cannot be considered to be exclusive, in that they interact with one another and culminate in persistent drug addiction behaviors (Koob and Le Moal 1997; Koob and Volkow 2010). Although significant advances in human neuroimaging and other techniques 
have allowed researchers to further our understanding of the neural substrates that underlie addiction, this review will primarily focus on data derived from various animal models to provide a broad overview of the neurobiology thought to underlie development of the different stages of addictive behaviors.

\section{DRUGS OF ABUSE AND COMMON NEUROBIOLOGY OF ADDICTION}

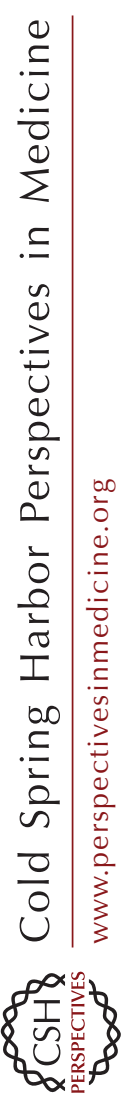

Drugs of abuse are generally classified into different categories, including narcotics (e.g., opiates), cannabinoids (e.g., marijuana), depressants (e.g., ethanol), psychostimulants (e.g., nicotine, amphetamines, and cocaine), hallucinogens (e.g., lysergic acid diethylamide and ecstasy), and inhalants (e.g., toluene and nitrous oxide). Although all drugs of abuse have the potential to produce feelings of euphoria and relieve negative emotional states (Nesse and Berridge 1997), their behavioral and neuropharmacological properties are highly diverse. However, when one considers the mechanism for their acute reinforcing effects, most researchers have focused their attention on the mesocorticolimbic DA pathway (Wise 1980). This system, which mediates the rewarding effects of both natural stimuli (e.g., food, drink, and sex) and drugs of abuse, consists of dopamine (DA) cell bodies in the ventral tegmental area (VTA) that project to various limbic (i.e., the mesolimbic pathway, including the nucleus accumbens (NAcc), ventral pallidum, amygdala, hippocampus, and the bed nucleus of the stria terminalis [BNST]) and cortical structures (i.e., the mesocortical pathway, including the prefrontal cortex [PFC], orbitofrontal cortex $[\mathrm{OFC}]$, and the anterior cingulate). Various drugs of abuse interact with this circuit at different levels (Cami and Farre 2003) and other neurotransmitter/neuromodulator systems, including opioid peptides, GABA, glutamate, and endocannabinoids play a role in the reinforcing effects of drugs of abuse (especially nonpsychostimulants). Moreover, whereas these circuits operate in parallel, evidence suggest that they have somewhat different roles in addiction (Cami and Farre 2003). Within the mesolimbic pathway, data suggests that the NAcc (Di Chiara 2002) and ventral pallidum are involved in the primary reinforcing effects of drugs of abuse (Volkow et al. 2003). On the other hand, the amygdala (specifically the basolateral amygdala [BLA] [See 2005]) and hippocampus (both the dorsal [Fuchs et al. 2005; Meyers et al. 2006; Atkins et al. 2008] and ventral [Rogers and See 2007; Lasseter et al. 2010b)] subregions) play a key role in discrete and/or contextual drugassociative learning. Within the mesocortical pathway, the PFC, OFC and anterior cingulate are involved in the regulation of emotional responses, cognitive control and executive function (Volkow et al. 1993), with long term drug use resulting in cellular adaptations in the prefrontal-NAcc glutamatergic pathway leading to persistent addictive behaviors, including the devaluation of natural rewards, diminished cognitive control, and hyper-responsiveness to drugassociated stimuli (Koob and Le Moal 2001; Kalivas and Volkow 2005). With respect to the stages of addiction outlined above, these data collectively suggest that the mesolimbic pathway (especially the VTA and NAcc) is involved in acute drug reinforcement and occasional drug use, the mesocortical pathway and associated areas (e.g., the dorsal striatum) are involved in escalation/dependence, whereas both pathways and associated areas are involved in mediating conditioned responses, drug craving, and loss of behavioral control thought to underlie withdrawal and relapse.

\section{NEUROCIRCUITRY INVOLVED IN ACUTE REINFORCEMENT/DRUG USE}

In general, predominant addiction theories suggest that the acute reinforcement produced by drugs of abuse involves direct or indirect enhancement of DA in the NAcc (Di Chiara and Imperato 1988; Koob and Bloom 1988). Interestingly, this system is similarly involved in the motivation and drive for natural reinforcers (Wise 2002); however, drugs of abuse produce more robust increases in accumbal DA that, unlike natural reinforcers, does not undergo adaptive change (i.e., habituation) with repeated experiences (Di Chiara 1999). These data suggest 
that the initiation of the addiction cycle not only involves drugs of abuse "hijacking" a system normally involved in the reward and reinforcement of naturally appetitive stimuli (Robbins and Everitt 1996), but this effect is persistent, adding to the consolidation of responses to drug-associated stimuli (Berke and Hyman 2000) and further promoting the repeated use of the addictive substance.

Much of our understanding of the neurobiology of the acute rewarding effects of drugs of abuse can be traced to the discovery of a brain reward system by Olds and Milner (1954). Using intracranial self-stimulation, they showed that animals would administer low levels of electrical current into a number of areas, the most sensitive of which involved the medial forebrain bundle projecting from the VTA to the basal forebrain (Olds and Milner 1954). Using this model, it has been shown that acute administration of drugs of abuse results in decreased brain stimulation reward thresholds (i.e., increased reward), with more addictive drugs producing greater reductions in thresholds (Kornetsky et al. 1979; Kornetsky and Bain 1990).

Further evidence implicating the role of DA and the mesolimbic pathway in acute drug reinforcement includes a number of studies using drug self-administration, which involves an animal performing an operant behavior (e.g., lever press) to receive a drug reinforcer. Using this model, it has been shown that systemic administration of DA synthesis inhibitors (Pickens et al. 1968; Wilson and Schuster 1974) or DA antagonists (Yokel and Wise 1975; Woolverton 1986; Corrigall and Coen 1991; Rassnick et al. 1992; Richardson et al. 1994) decreases self-administration of a variety of drugs of abuse, including psychostimulants, opiates, nicotine, and ethanol. Moreover, excitotoxic lesions of the NAcc block cocaine, heroin (Zito et al. 1985), and morphine self-administration (Dworkin et al. 1988b), with similar effects showed using 6-hydroxydopamine (6-OHDA) to selectively lesion DA pathways in the NAcc (Roberts et al. 1977, 1980; Lyness et al. 1979; Corrigall et al. 1992) or VTA (Roberts and Koob 1982). In addition, in vivo microdialysis studies have shown increases in extracellular DA in the NAcc during psychostimulant (Hurd et al. 1989; Pettit and Justice 1989; Weiss et al. 1992; Di Ciano et al. 1995; Meil et al. 1995; Pontieri et al. 1995, 1996; Wise et al. 1995b) and opiate (Hemby et al. 1995; Pontieri et al. 1995; Wise et al. 1995a) self-administration. Similar effects occur during the self-administration of a variety of other drugs of abuse, including nicotine (Pontieri et al. 1996; Lecca et al. 2006b), cannabinoids (Fadda et al. 2006; Lecca et al. 2006a), and ethanol (Weiss et al. 1993; Melendez et al. 2002; van Erp and Miczek 2007). Finally, a number of studies have shown that animals will reliably self-administer intracranial microinjections of various drugs of abuse (Myers 1974; Bozarth 1987), further supporting the role of the mesolimbic pathway in addiction. For example, animals will reliably self-administer psychostimulants, opiates, and ethanol into the NAcc (Monaco et al. 1981; Olds 1982; Hoebel et al. 1983; Chevrette et al. 2002; Rodd-Henricks et al. 2002) or VTA (van Ree and de Wied 1980; Bozarth and Wise 1981, 1982; Gatto et al. 1994; Rodd et al. 2004a,b, 2005). Moreover, these effects appear relatively selective, in that switching the response contingency, replacing the drug with artificial cerebrospinal fluid, or examination of other nonassociative brain regions eliminates or prevents these behaviors.

Despite abundant evidence for its role in psychostimulant reward, there has been some debate regarding the necessity of the mesolimbic DA system for the acute reinforcing effects of other drugs of abuse (Koob 1992; Nestler 2005). In one example, 6-OHDA lesions of the NAcc, which reliably impair psychostimulant administration, generally fail to alter the self-administration of opiates (Ettenberg et al. 1982; Pettit et al. 1984; Smith et al. 1985; Dworkin et al. 1988a) or ethanol (Lyness and Smith 1992; Rassnick et al. 1993). Similar effects have also been reported for DA antagonists on opiate selfadministration (Ettenberg et al. 1982; Gerrits et al. 1994), collectively suggesting that nonpsychostimulant drugs of abuse may additionally involve DA-independent mechanisms of reinforcement. In support of this hypothesis, systemic or intracranial administration of opioid 
antagonists attenuate heroin (Bozarth and Wise 1983; Corrigall and Vaccarino 1988) and ethanol (Altshuler et al. 1980; Samson and Doyle 1985 ) self-administration. The endogenous cannabinoid system may also be involved in mediating opiate and ethanol reinforcement, in that genetic knockout (Ledent et al. 1999; Cossu et al. 2001; Hungund et al. 2003; Thanos et al. 2005) or antagonism of $\mathrm{CB}_{1}$ receptors (Caille and Parsons 2003; Colombo et al. 2005) can reduce opiate or ethanol intake. Interestingly, this effect appears specific to nonpsychostimulants, in that genetic deletion of $\mathrm{CB}_{1}$ receptors had no effect on cocaine, amphetamine, or nicotine self-administration (Cossu et al. 2001), but see Soria et al. (2005).

The collective evidence supports the notion that whereas opiate and ethanol reinforcement involves mesolimbic DA activity (Johnson and North 1992; Weiss et al. 1993), both DA-dependent and -independent mechanisms exist (Van Ree et al. 1999). Thus, although other neurotransmitter/neuromodulator systems are significantly involved in the acute reinforcing effects of numerous drugs of abuse (Koob and Le Moal 2006), the weight of evidence suggests that the mesolimbic DA system is critically involved in the reinforcing properties of drugs and, as such, the initiation of the addiction cycle. However, DA may play a differential role in chronic addictive states via alterations in mediating the reinforcing effects of drug (i.e., "liking") to the persistence of addictive behaviors in drug dependence (i.e., "wanting”) (Berridge 2007).

\section{NEUROCIRCUITRY INVOLVED IN DRUG DEPENDENCE}

In addition to the role of DA in mediating the acute reinforcement of drugs during occasion$\mathrm{al} /$ controlled drug use, DA activity in the mesocorticolimbic system may further promote continued, persistent drug-seeking behaviors by enhancing learning about the associations between actions and discrete, environmental, or contextual stimuli involved in the drug-taking process (Everitt et al. 2001). With repeated drug taking (i.e., as the state of drug dependence develops), these drug-associated stimuli even- tually begin to dominate the behavioral output independent of goal-directed action (Everitt and Robbins 2005). These conditioned drug associations can be considered to be a form of maladaptive learning that eventually acquires an increasing role in mediating drug seeking behavior. Interactions between Pavlovian and instrumental learning processes (Everitt et al. 2001) can lead to a shift from "stimulus-reward" to "stimulus-response" learning that underlies the habitual drug seeking characteristic of chronic drug dependence. As such, this loss of controlled drug-seeking and drug-taking behavior, which is the hallmark of clinical drug addiction/dependence, has become increasingly of interest for preclinical researchers (Wolffgramm and Heyne 1995; Deroche-Gamonet et al. 2004; Vanderschuren and Everitt 2004).

The concept of drug addiction as a maladaptive and persistent habit comes from several sources, with abundant data suggesting a transition at the neuronal level from the ventral to the dorsal striatum, likely involving a progressive recruitment by spiraling DA circuitry connections within the midbrain (Haber et al. 2000; Ikemoto 2007). In contrast to the ventral striatum (i.e., the NAcc), the dorsal striatum (especially the lateral regions) appears to have little, if any, role in the acute reinforcing effects of drugs of abuse but does appear to be engaged during the development of compulsive drug seeking (Everitt et al. 2008). For example, 6OHDA (Roberts 1992) or excitotoxic (Gabriele and See 2011) lesions of the dorsal striatum do not have any effect on cocaine self-administration. When a selective lesion of the NAcc core was paired with an infusion of the DA receptor antagonist, $\alpha$-flupenthixol, into the contralateral dorsal striatum, no effect was observed in animals immediately after acquisition. However, this procedure resulted in attenuated cocaine seeking once stable responding was achieved on a second order schedule of reinforcement (Belin and Everitt 2008). In rhesus monkeys, Porrino and colleagues showed progressively greater activation of the dorsal and lateral regions of the striatum as assessed by 2-deoxyglucose autoradiography following 100 , but not 5 , days of cocaine self-administration (Porrino et al. 2004). 
Similar data in primates showed progressive ventral-to-dorsal changes in DA transporter (Letchworth et al. 2001) and receptor (Nader et al. 2002) expression following long-term cocaine self-administration. Furthermore, microdialysis data in rats have indicated that contingent presentation of a cocaine-paired stimulus on a second order schedule of reinforcement increases extracellular DA levels in the dorsal striatum, but not NAcc, following chronic cocaine self-administration (Ito et al. 2000, 2002). Using a similar second order model, administration of $\alpha$-flupenthixol into the dorsolateral striatum blocked responding for a cocaine-associated cue; however, treatment in the NAcc was without effect (Di Ciano and Everitt 2004b; Vanderschuren et al. 2005). A similar anatomical dissociation has been noted using GABA agonist inhibition in a contextual model of cocaine seeking, in which inactivation of the dorsolateral striatum (Fuchs et al. 2006a; See et al. 2007), but not the NAcc (See et al. 2007), following abstinence from chronic cocaine self-administration resulted in decreased cocaine seeking. Finally, a recent report showed that not only did extensive training on a cocaine-seeking schedule lead to a transition from goal-directed to habitual behavior (as measured by a failure to devalue the drug-taking response by contingency degradation through extinction), but also that transient inactivation of the dorsolateral striatum reduced cocaine seeking only when the drug-taking response had been devalued (Zapata et al. 2010). Combined with clinical data indicating that elevations of DA in the dorsal, but not ventral, striatum positively correlate with cue-induced craving in cocaine-dependent patients (Volkow et al. 2006; Wong et al. 2006), these data collectively suggest that the dorsal striatum becomes progressively involved in mediating drug seeking during the transition from initial voluntary use to the habitual, loss of control behavior characteristic of chronic drug addiction and dependence.

In addition to the dorsal striatum, an abundance of evidence suggests that prefrontal cortical areas may also play a role in mediating compulsive drug-seeking behavior, likely involving a loss of behavioral control and inhibi- tion. Although habitual behaviors primarily involve cortico-striatal-thalamic circuitry (Jog et al. 1999; Canales 2005), these behaviors rely on higher level cortical processing of new information to determine if the behavior needs to be modified according to its adaptive function. As such, if the behavior becomes maladaptive, information of this unfavorable outcome from the PFC should lead to a modification or cessation of the behavior. However, despite a number of negative consequences, drug taking continues in drug-dependent individuals. Interestingly, a number of studies have shown decreased gray matter density and reduced baseline blood glucose metabolism in frontal cortical areas, including the anterior cingulate and OFC, of chronic drug users (London et al. 1999; Volkow and Fowler 2000; Franklin et al. 2002; Matochik et al. 2003; Thompson et al. 2004; Ersche et al. 2011).

Chronic cocaine abusers exhibit deficits in inhibitory control and decision-making processes (Bolla et al. 2003; Hester and Garavan 2004). In animal models, lesions of the medial PFC (mPFC), including the prelimbic and infralimbic cortex, result in enhanced acquisition of cocaine self-administration and increased responding for cocaine on a second order schedule of reinforcement (Weissenborn et al. 1997). These effects do not appear to be caused by an alteration in reinforcement (Burns et al. 1993), but rather a loss in behavior/inhibition processes (Dalley et al. 2004). Furthermore, reversible inactivation of the infralimbic cortex in rodents leads to reinstatement of extinguished cocaine seeking (Peters et al. 2008). In addition, there is an abundance of preclinical data to suggest that OFC dysfunction is significantly involved in addiction behaviors (Schoenbaum et al. 2006; Everitt et al. 2007; Olausson et al. 2007; Lucantonio et al. 2012). Similar decision-making problems have been shown for patients with OFC damage (Rogers et al. 1999), suggesting that chronic drug taking may be a casual factor for PFC-dependent deficiencies. In contrast, preexisting deficits in prefrontal cortical function (Volkow and Fowler 2000; Kaufman et al. 2003; Hester and Garavan 2004) may have led to poor decision capacities contributing to the 
development of the addiction. However, a number of experimental studies in rodents and nonhuman primates support the view that these deficits are likely a consequence of chronic drug use history (Jentsch and Taylor 1999; Schoenbaum et al. 2006). In animals withdrawn from chronic drug exposure, psychostimulants had a profound effect on dendritic morphology (e.g., dendritic length and spine density) in the OFC and PFC (Kolb et al. 2004; Crombag et al. 2005), as well as increases in the transcription factor $\Delta$ FosB during early withdrawal from chronic cocaine (Winstanley et al. 2007). Similar drug exposure paradigms (including self-administration models) have shown evidence for cognitive inflexibility and impulsive behaviors that are relevant to addiction in humans. These include cognitive deficits on various learning tasks, such as reversal learning-deficits associated with damage to the OFC (Calu et al. 2007; Izquierdo et al. 2010; Porter et al. 2011) and extradimensional shifting-deficits associated with damage to the medial PFC (Parsegian et al. 2011), as well as enhanced impulsivity (Roesch et al. 2007; Simon et al. 2007). Taken together, these data suggest that impairments in prefrontal cortical areas following prolonged drug use may lead to the persistence of addiction behaviors by producing deficits in adaptive decision-making and behavioral control. However, these areas also likely contribute to drug seeking by enhancing the saliency and motivational significance of stimuli known to promote relapse in drug-dependent individuals.

\section{NEUROBIOLOGY UNDERLYING RELAPSE}

As previously mentioned, relapse to drug use following prolonged periods of abstinence constitutes one of the most significant problems for the long-term treatment of drug-dependent individuals (Dackis and O'Brien 2001; Wagner and Anthony 2002). A number of factors contribute to craving and relapse, including exposure to environmental stimuli previously paired with drug use (i.e., conditioned drug cues), negative mood states or stress, and exposure to small amounts of the drug. For example, abstinent cocaine users report increases in drug crav- ing when exposed to cocaine-associated stimuli (Childress et al. 1993), following stressful life events (Sinha et al. 1999), and in response to noncontingent cocaine doses (Jaffe et al. 1989). These trigger factors have been used in animal models of relapse to drug seeking, particularly in the extinction-reinstatement model following withdrawal from chronic drug self-administration (de Wit and Stewart 1981; Kalivas and McFarland 2003; Shaham et al. 2003). Typically, animals that previously self-administered a drug (usually paired with a discrete stimulus, such as light and/or tone) undergo extinction trials, whereby responding on the previously drug-paired lever no longer results in primary reinforcement. Exposure to the previously drugpaired cues, an environmental stressor, or noncontingent drug administration can robustly reinstate drug seeking (i.e., induce relapse) as indexed by increased responding on the previously drug-paired operandum (Shaham et al. 2003). As such, the extinction-reinstatement model has been useful for extensive exploration of the neural circuitry underlying relapse-like behaviors (Meil and See 1997; Neisewander et al. 2000; McFarland and Kalivas 2001; McFarland et al. 2004).

Using reinstatement models, a number of laboratories have contributed to our understanding of the neurocircuitry of relapse. In studies on cue-associated drug seeking, evidence suggests an important role for a number of mesocorticolimbic structures, especially the BLA and prefrontal cortical areas (including the anterior cingulate, prelimbic, and orbitofrontal cortices), via glutamatergic and DAergic interactions with the NAcc core. Consistent with neuroimaging studies demonstrating increases in metabolic activity in the amygdala in abstinent cocaine users exposed to drug-associated cues or drug-related imagery (Grant et al. 1996; Childress et al. 1999; Kilts et al. 2001, 2004; Bonson et al. 2002), reinstatement of cocaine seeking in rats exposed to discrete cocaine-associated cues positively correlates with increased Fos expression in the BLA (Kufahl et al. 2009). Moreover, permanent lesions or reversible inactivation of the BLA has a number of effects on discrete cueinduced drug seeking, including decreases in 
responding for stimuli associated with cocaine reinforcement (Whitelaw et al. 1996; Meil and See 1997; Grimm and See 2000), and prevention of the acquisition (Kruzich and See 2001), consolidation (Fuchs et al. 2006b; Gabriele and See 2010), and expression (Kruzich and See 2001; Fuchs and See 2002; McLaughlin and See 2003; Rogers et al. 2008) of cocaine- or heroin-seeking behavior. A similar role for the BLA in contextual drug seeking has also been found (Fuchs et al. 2005, 2009), involving interactions with other areas implicated in cue-mediated drug seeking, including prefrontal cortical areas (Fuchs et al. 2007; Lasseter et al. 2011) and the hippocampus (Fuchs et al. 2005; Wells et al. 2011).

Presentation of stimuli associated with cocaine availability results in a significant elevation in extracellular DA in the BLA (Weiss et al. 2000). In addition to direct intra-BLA administration of DA receptor antagonists attenuating cocaine seeking on a second-order schedule of reinforcement (Di Ciano and Everitt 2004b), similar treatment has also been shown to attenuate the acquisition (Berglind et al. 2006) and expression (See et al. 2001) of discrete cue-induced reinstatement. Moreover, elevations in Fos (Neisewander et al. 2000; Ciccocioppo et al. 2001) and Fos-related antigen (Franklin and Druhan 2000) expression noted when animals are exposed to contextual or discrete cocaineassociated cues can be reversed by $\mathrm{DA}_{1}$ receptor antagonism (Ciccocioppo et al. 2001). Other neurotransmitter systems, including glutamate (See et al. 2001; Feltenstein and See 2007) and acetylcholine (See et al. 2003), have also been shown to be involved in BLA-mediated cue-associative learning. Taken together, these results suggest that the BLA plays a prominent role in drug-cue associative learning and relapse, with different neurotransmitter systems likely mediating unique aspects of amygdalar processing of drug-paired stimuli.

Similar to the BLA, imaging studies have not only showed increases in metabolic activity in the PFC (specifically the dorsolateral regions) when drug-dependent individuals are exposed to drug-associated cues (Grant et al. 1996), but this activation was also positively correlated with craving (Maas et al. 1998; Bonson et al. 2002). In animal models, increases in reinstatement behavior and Fos protein or Arc mRNA expression noted in the dorsomedial PFC (dmPFC) when animals are exposed to discrete cocaine- (Zavala et al. 2008; Kufahl et al. 2009) or heroin-paired cues (Koya et al. 2006), as well as discriminative stimuli predicting cocaine (Ciccocioppo et al. 2001) or ethanol availability (Dayas et al. 2007), can be blocked by DA $D_{1}$ receptor antagonism (Ciccocioppo et al. 2001). Inactivation studies, including use of the sodium channel blockers tetrodotoxin (McLaughlin and See 2003; Fuchs et al. 2005) or lidocaine (Di Pietro et al. 2006) or the $\mathrm{GABA}_{\mathrm{A}}$ and $\mathrm{GABA}_{\mathrm{B}}$ agonists, muscimol and baclofen (Fuchs et al. 2007; LaLumiere and Kalivas 2008; Rogers et al. 2008), have been shown to inhibit reinstatement of drug seeking when animals are exposed to discrete or contextual cocaine- or heroin-associated cues. Moreover, mediation of cue-associated reinstatement by the $\mathrm{dmPFC}$ likely involves glutamatergic innervation of the NAcc core, in that inhibition of heroin seeking following reversible inactivation of the $\mathrm{dmPFC}$ also prevents concomitant increases in glutamate within the NAcc core (LaLumiere and Kalivas 2008). This same study further supported this hypothesis by demonstrating that glutamate AMPA/kainate receptor antagonism in the NAcc also inhibits discrete cue-induced heroin seeking. Although studies examining the putative role of the infralimbic cortex in cue-mediated drug seeking have been mixed (see Lasseter et al. (2010a) for review), it appears that the lateral, but not medial, $\mathrm{OFC}$ is also involved in these types of drug-seeking behaviors, in that inactivation attenuates both discrete and contextual cue-induced cocaine seeking (Gallagher et al. 1999; Fuchs et al. 2004b; Lasseter et al. 2009).

Similar to the BLA and prefrontal cortices, a substantial amount of data suggests that the $\mathrm{NAcc}$ is significantly involved in cue-induced drug seeking. Exposure to discrete or contextual cocaine (Neisewander et al. 2000; Kufahl et al. 2009) or ethanol (Dayas et al. 2007) associated cues have been shown to induce Fos in the NAcc, with numerous studies demonstrating a particular role for the NAcc core, in that reversible inactivation selectively attenuates cocaine 
seeking (Di Ciano and Everitt 2004a; Fuchs et al. 2004a; Di Ciano et al. 2008). With respect to specific neurotransmitter systems, microdialysis and antagonist studies have indicted a particular role for DA and glutamate in mediating these behaviors. For example, exposure to discriminative stimuli predicting cocaine availability results in a robust elevation in DA in the NAcc (Weiss et al. 2000), with $\mathrm{DA}_{1}$ receptor antagonism in the core, but not shell, decreasing drug seeking in animals exposure to discrete or contextual cues associated with heroin availability (Bossert et al. 2007). Direct infusion of AMPA or NMDA agonists into the NAcc results in reinstatement of cocaine seeking (Cornish et al. 1999), whereas AMPA/kainate and/or NMDA receptor antagonism has been shown to block cocaine seeking following exposure to drug-associated cues on a second-order schedule (Di Ciano and Everitt 2001; Backstrom and Hyytia 2007). Although other neurotransmitter systems in the NAcc may play a role in mediating cue-induced drug seeking (e.g., acetylcholine [Zhou et al. 2007), these data collectively suggest that cue-associated reinstatement relies on glutamate and DA interactions between the NAcc core, BLA, and dmPFC.

Similar to cue-induced drug seeking, a considerable amount of research suggests that prefrontal cortical areas, the NAcc (in particular the core), and the VTA are critically involved in mediating reinstatement following exposure to the previously self-administered drug (McFarland and Kalivas 2001). In addition to the ventral pallidum, inactivation of these regions has been shown to attenuate cocaine- (Grimm and See 2000; McFarland and Kalivas 2001; Capriles et al. 2003) or heroin-primed reinstatement (Rogers et al. 2008). Examination of the role of various neurotransmitter systems in mediating these behaviors suggests that DA and glutamate play a pivotal role in drug-primed relapse-like behaviors. For example, microdialysis studies have shown increases in accumbal DA and glutamate following a priming injection of cocaine (McFarland et al. 2003). Similarly, microinfusions of DA or glutamate, as well as AMPA agonists, into the NAcc alone produce robust elevations in drug seeking (Cornish et al. 1999; McFarland and Kalivas 2001), with $\mathrm{DA} \mathrm{D}_{1}$ receptor antagonism in the shell (Anderson et al. 2003) or AMPA/kainic receptor antagonists in the core (Cornish and Kalivas 2000) attenuating cocaine-primed reinstatement. Interestingly, DA or NMDA antagonism in the core were without effect, collectively suggesting divergent roles for DA and glutamate (via AMPA receptors) in the NAcc shell and core, respectively, for mediating cocaine-primed reinstatement.

With respect to prefrontal cortical areas, dmPFC inactivation can impair drug-primed heroin, cocaine, methamphetamine, and nicotine seeking (McFarland and Kalivas 2001; Capriles et al. 2003; Zavala et al. 2003; Hiranita et al. 2006; Rogers et al. 2008). Moreover, direct infusions of DA, cocaine, or amphetamine into the $\mathrm{dmPFC}$ can elicit cocaine seeking, whereas DA $D_{1}$ and $D_{2}$ receptor antagonists have been shown to disrupt cocaine-primed reinstatement and conditioned place preference (McFarland and Kalivas 2001; Park et al. 2002; Sanchez et al. 2003; Sun and Rebec 2005), but see Capriles et al. (2003). The role for the dmPFC in mediating these behaviors appears to include glutaminergic inputs into the NAcc core, in that an enhancement in glutamate release and drug seeking following a cocaine- or heroinprime are both reversed following dmPFC inactivation (McFarland et al. 2003; LaLumiere and Kalivas 2008).

As previously mentioned, stress has been shown to play a prominent role in the initiation and maintenance of substance dependence disorders (Higgins and Marlatt 1975; Russell and Mehrabian 1975; Koob and Le Moal 2001). In animals models of relapse, researchers have used a variety of techniques, including exposure to footshock (Erb et al. 1996; McFarland et al. 2004; Buffalari and See 2009) or pharmacological stressors (Lee et al. 2004; Shepard et al. 2004; Le et al. 2005; Buffalari et al. 2012), to model stress-induced relapse-like behaviors. As such, examination of the neurocircuitry involved in stress-induced reinstatement using these methods suggests both overlapping, yet distinct, neural systems mediating these behaviors relative to other forms of reinstatement (Stewart 2000; Shaham et al. 2003). Similar to 
other forms of relapse, inactivation of prefrontal cortical areas, the NAcc, or the VTA has been shown to decrease stress-induced reinstatement, with a unique contribution noted for the BNST and central nucleus of the amygdala (CeA) in mediating these behaviors (Capriles et al. 2003; McFarland et al. 2004). Although it has been suggested that DA only plays a modulatory role in stress-induced reinstatement (Shaham et al. 2000a), DA activity in prefrontal cortical areas, including the PFC (Capriles et al. 2003; Sanchez et al. 2003) and OFC (Capriles et al. 2003), appears to critically mediate these behaviors, in that DA receptor antagonist administration into these regions blocks stress-induced drug seeking. It has also been shown that corticotrophin-releasing factor (CRF) and norepinephrine (NE), likely involving interactions between the BNST and CeA (Erb et al. 2001), are critically and selectively involved in stressmediated reinstatement. Intracerebroventricular (ICV) administration of CRF alone induces reinstatement of heroin (Shaham et al. 1997) or cocaine seeking (Buffalari et al. 2012), whereas ICV or intra-BNST administration of CRF antagonists (Shaham et al. 1997; Erb et al. 1998; Erb and Stewart 1999; Le et al. 2000) attenuates footshock-induced reinstatement. Similar attenuations in drug seeking have been noted following pretreatment with compounds that attenuate NE activity (Erb et al. 2000; Shaham et al. 2000b; Highfield et al. 2001), including intra-BNST or CeA administration (Leri et al. 2002). Taken together, it appears that CRF and $\mathrm{NE}$ activity within the BNST and CeA, as well as interactions of these systems with the NAcc (uniquely involving the shell; McFarland et al. 2004) and PFC, may be critically involved in stress-induced drug craving and relapse when addicts are exposed to stressful stimuli.

In summary, it appears that three distinct, yet overlapping, neurocircuits mediate relapselike behaviors following exposure to drug-associated cues, drug, or stressful events (Kalivas and McFarland 2003; Shaham et al. 2003). Thus, although there are a number of unique aspects involved in each type of reinstatement, these data collectively suggest that projections from the VTA (all forms of reinstatement), lim- bic regions including the BLA (cue reinstatement), CeA, BNST, and NAcc shell (stress reinstatement) converge on motor pathways involving the dmPFC and NAcc core that represent a "final common pathway" for all three types of instigating factors in relapse. It should be noted, however, that recent discoveries have implicated other brain structures and neurotransmitter systems in drug seeking behaviors. As mentioned previously, a considerable amount of research has implicated the dorsal (Fuchs et al. 2005, 2007; Meyers et al. 2006; Atkins et al. 2008; Ramirez et al. 2009; Xie et al. 2010; Wells et al. 2011) and ventral (Rogers and See 2007; Lasseter et al. 2010b) hippocampus in cue-induced relapse, including discrete and contextual forms of associative learning. Additionally, a newly defined region, called the mesopontine rostromedial tegmental nucleus (RMTg; also known as the tail of the VTA) (Jhou et al. 2009; Kaufling et al. 2009; Lavezzi and Zahm 2011) has been implicated as potentially having a profound role in reward-related behaviors. Receiving projections from a number of regions, including the medial PFC, ventral pallidum, BNST and lateral habenula (Kaufling et al. 2009), and consisting primarily of GABAergic neurons, the RMTg projects to the VTA and has been implicated as likely having a modulatory role on VTA-mediated drug reward and relapse (Jalabert et al. 2011; Lecca et al. 2011). Another region that has received interest for its potential role in addiction, particularly nicotine dependence, is the pedunculopontine tegmental nucleus (PPTg) (Maskos 2008; Mark et al. 2011). Providing cholinergic innervation to the VTA, it has been suggested that the posterior PPTg is involved in drug reinforcement (Alderson et al. 2006), with lesion and/or selective nicotinic receptor antagonism studies demonstrating an attenuation of nicotine (Lanca et al. 2000; Corrigall et al. 2001) and cocaine self-administration behaviors (Corrigall et al. 2002). Finally, the neuropeptide orexin (also know as hypocretin), which is predominantly located in neurons in the lateral hypothalamus, has recently been found to play a significant role in mediating drug addiction and relapse (Harris et al. 2005), including cocaine- (Boutrel et al. 2005; Smith 
Neural Systems in Addiction

et al. 2009, 2010; Zhou et al. 2012), heroin(Smith and Aston-Jones 2012), ethanol- (Lawrence et al. 2006; Richards et al. 2008; Shoblock et al. 2011), and nicotine-seeking behaviors (Plaza-Zabala et al. 2010). Another neuropeptide, oxytocin, has also received some interest recently for its potential as a therapeutic for drug addiction (Sarnyai 2011; McGregor and Bowen 2012).

\section{CONCLUSIONS}

Drug addiction is a chronic disease that encompasses a large number of social, economic, and medical issues that can persist even years after abstinence (Meyer 1996). As such, a considerable amount of research has been devoted to understanding the behavioral and neurobiological mechanisms that mediate the transition from casual drug use to the loss of control and persistence of drug-seeking behaviors that characterize drug addiction and dependence. Using various animal models of addiction, researchers have been able to determine aspects of the fundamental neurobiology involved in drug seeking across the entire addiction cycle, including the acute reinforcing effects of drugs, the neuroadaptations that occur during the transition to drug dependence, and finally the relatively permanent alterations in these systems that leave an individual susceptible to relapse. Although the role of neurotransmitters/neuromodulators and neural systems can vary across drugs of abuse and stages of the addiction cycle, evidence shows that the mesocorticolimbic pathway, including the VTA, NAcc, amygdala, and prefrontal cortices via DA and glutamate pathways, play a significant role in addiction. With a better understanding of the neurobiological factors that underlie drug addiction, continued clinical and preclinical research will greatly facilitate the development of novel therapeutic interventions that may result in better, more effective treatment strategies for drug-dependent individuals.

\section{ACKNOWLEDGMENTS}

The work of the authors was supported by National Institutes of Health Grants P50
DA015369, P50 DA016511, P20 DA022658, R01 DA010462, and R01 DA021690.

\section{REFERENCES}

Alderson HL, Latimer MP, Winn P. 2006. Intravenous selfadministration of nicotine is altered by lesions of the posterior, but not anterior, pedunculopontine tegmental nucleus. Eur J Neurosci 23: 2169-2175.

Altshuler HL, Phillips PE, Feinhandler DA. 1980. Alteration of ethanol self-administration by naltrexone. Life Sci 26: 679-688.

American Psychiatric Association. 1994. Diagnostic and statistical manual of mental disorders. American Psychiatric Press, Washington, DC.

Anderson SM, Bari AA, Pierce RC. 2003. Administration of the D1-like dopamine receptor antagonist SCH-23390 into the medial nucleus accumbens shell attenuates cocaine priming-induced reinstatement of drug-seeking behavior in rats. Psychopharmacology 168: 132-138.

Atkins AL, Mashhoon Y, Kantak KM. 2008. Hippocampal regulation of contextual cue-induced reinstatement of cocaine-seeking behavior. Pharmacol Biochem Behav 90: 481-491.

Backstrom P, Hyytia P. 2007. Involvement of AMPA/kainate, NMDA, and mGlu5 receptors in the nucleus accumbens core in cue-induced reinstatement of cocaine seeking in rats. Psychopharmacology 192: 571-580.

Belin D, Everitt BJ. 2008. Cocaine seeking habits depend upon dopamine-dependent serial connectivity linking the ventral with the dorsal striatum. Neuron 57: 432-441.

Berglind WJ, Case JM, Parker MP, Fuchs RA, See RE. 2006. Dopamine D1 or D2 receptor antagonism within the basolateral amygdala differentially alters the acquisition of cocaine-cue associations necessary for cue-induced reinstatement of cocaine-seeking. Neuroscience 137: 699-706.

Berke JD, Hyman SE. 2000. Addiction, dopamine, and the molecular mechanisms of memory. Neuron 25: 515-532.

Berridge KC. 2007. The debate over dopamine's role in reward: The case for incentive salience. Psychopharmacology 191: 391-431.

Berridge KC, Robinson TE. 1995. The mind of an addicted brain: Neural sensitization of wanting versus liking. Curr Direct Psychol Sci 4: 71-76.

Bolla KI, Eldreth DA, London ED, Kiehl KA, Mouratidis M, Contoreggi C, Matochik JA, Kurian V, Cadet JL, Kimes AS, et al. 2003. Orbitofrontal cortex dysfunction in abstinent cocaine abusers performing a decision-making task. Neuroimage 19: 1085-1094.

Bonson KR, Grant SJ, Contoreggi CS, Links JM, Metcalfe J, Weyl HL, Kurian V, Ernst M, London ED. 2002. Neura systems and cue-induced cocaine craving. Neuropsychopharmacology 26: 376-386.

Bossert JM, Poles GC, Wihbey KA, Koya E, Shaham Y. 2007. Differential effects of blockade of dopamine D1-family receptors in nucleus accumbens core or shell on reinstatement of heroin seeking induced by contextual and discrete cues. J Neurosci 27: 12655-12663.

Boutrel B, Kenny PJ, Specio SE, Martin-Fardon R, Markou A, Koob GF, de Lecea L. 2005. Role for hypocretin 
M.W. Feltenstein and R.E. See

in mediating stress-induced reinstatement of cocaineseeking behavior. Proc Natl Acad Sci 102: 19168-19173.

Bozarth MA. 1987. Intracranial self-administration procedures for the assessment of drug reinforcement. In Meth ods of assessing the reinforcing properties of abused drugs (ed. Bozarth MA), pp. 173-187. Springer-Verlag, New York.

Bozarth MA, Wise RA. 1981. Intracranial self-administration of morphine into the ventral tegmental area in rats. Life Sci 28: 551-555.

Bozarth MA, Wise RA. 1982. Localization of the rewardrelevant opiate receptors. NIDA Res Monog 41: 158-164.

Bozarth MA, Wise RA. 1983. Neural substrates of opiate reinforcement. Prog Neuropsychopharmacol Biol Psychiatry 7: 569-575.

Buffalari DM, See RE. 2009. Footshock stress potentiates cue-induced cocaine-seeking in an animal model of relapse. Physiol Behav 98: 614-617.

Buffalari DM, Baldwin CK, Feltenstein MW, See RE. 2012. Corticotrophin releasing factor (CRF) induced reinstatement of cocaine seeking in male and female rats. Physiol Behav 105: 209-214.

Burns LH, Robbins TW, Everitt BJ. 1993. Differential effects of excitotoxic lesions of the basolateral amygdala, ventral subiculum and medial prefrontal cortex on responding with conditioned reinforcement and locomotor activity potentiated by intra-accumbens infusions of $\mathrm{D}$-amphetamine. Behav Brain Res 55: 167-183.

Caille S, Parsons LH. 2003. SR141716A reduces the reinforcing properties of heroin but not heroin-induced increases in nucleus accumbens dopamine in rats. Eur J Neurosci 18: $3145-3149$.

Calu DJ, Stalnaker TA, Franz TM, Singh T, Shaham Y, Schoenbaum G. 2007. Withdrawal from cocaine self-administration produces long-lasting deficits in orbitofrontal-dependent reversal learning in rats. Learn Mem 14: 325-328.

Cami J, Farre M. 2003. Drug addiction. N Engl J Med 349: 975-986.

Canales JJ. 2005. Stimulant-induced adaptations in neostriatal matrix and striosome systems: Transiting from instrumental responding to habitual behavior in drug addiction. Neurobiol Learn Mem 83: 93-103.

Capriles N, Rodaros D, Sorge RE, Stewart J. 2003. A role for the prefrontal cortex in stress- and cocaine-induced reinstatement of cocaine seeking in rats. Psychopharmacology 168: 66-74.

Chevrette J, Stellar JR, Hesse GW, Markou A. 2002. Both the shell of the nucleus accumbens and the central nucleus of the amygdala support amphetamine self-administration in rats. Pharmacol Biochem Behav 71: 501-507.

Childress AR, Hole AV, Ehrman RN, Robbins SJ, McLellan AT, O'Brien CP. 1993. Cue reactivity and cue reactivity interventions in drug dependence. NIDA Res Monogr 137: 73-95.

Childress AR, Mozley PD, McElgin W, Fitzgerald J, Reivich M, O’Brien CP. 1999. Limbic activation during cue-induced cocaine craving. Am J Psychiatry 156: 11-18.

Ciccocioppo R, Sanna PP, Weiss F. 2001. Cocaine-predictive stimulus induces drug-seeking behavior and neural activation in limbic brain regions after multiple months of abstinence: Reversal by D1 antagonists. Proc Natl Acad Sci 98: 1976-1981.

Clark D, Overton PG. 1998. Alterations in excitatory amino acid-mediated regulation of midbrain dopaminergic neurones induced by chronic psychostimulant administration and stress: Relevance to behavioural sensitization and drug addiction. Addict Biol 3: 109-135.

Colombo G, Serra S, Vacca G, Carai MA, Gessa GL. 2005. Endocannabinoid system and alcohol addiction: Pharmacological studies. Pharmacol Biochem Behav 81: 369380.

Cornish JL, Kalivas PW. 2000. Glutamate transmission in the nucleus accumbens mediates relapse in cocaine addiction. J Neurosci 20: RC89.

Cornish JL, Duffy P, Kalivas PW. 1999. A role for nucleus accumbens glutamate transmission in the relapse to cocaine-seeking behavior. Neuroscience 93: 1359-1367.

Corrigall WA, Coen KM. 1991. Selective dopamine antagonists reduce nicotine self-administration. Psychopharmacology 104: 171-176.

Corrigall WA, Vaccarino FJ. 1988. Antagonist treatment in nucleus accumbens or periaqueductal grey affects heroin self-administration. Pharmacol Biochem Behav 30: $443-$ 450.

Corrigall WA, Franklin KB, Coen KM, Clarke PB. 1992. The mesolimbic dopaminergic system is implicated in the reinforcing effects of nicotine. Psychopharmacology 107: 285-289.

Corrigall WA, Coen KM, Zhang J, Adamson KL. 2001. GABA mechanisms in the pedunculopontine tegmental nucleus influence particular aspects of nicotine self-administration selectively in the rat. Psychopharmacology 158: 190-197.

Corrigall WA, Coen KM, Zhang J, Adamson L. 2002. Pharmacological manipulations of the pedunculopontine tegmental nucleus in the rat reduce self-administration of both nicotine and cocaine. Psychopharmacology 160: 198-205.

Cossu G, Ledent C, Fattore L, Imperato A, Bohme GA, Parmentier M, Fratta W. 2001. Cannabinoid CB1 receptor knockout mice fail to self-administer morphine but not other drugs of abuse. Behav Brain Res 118: 61-65.

Crombag HS, Gorny G, Li Y, Kolb B, Robinson TE. 2005. Opposite effects of amphetamine self-administration experience on dendritic spines in the medial and orbital prefrontal cortex. Cereb Cortex 15: 341-348.

Dackis CA, O’Brien CP. 2001. Cocaine dependence: A disease of the brain's reward centers. J Subst Abuse Treat 21: $111-117$.

Dalley JW, Cardinal RN, Robbins TW. 2004. Prefrontal executive and cognitive functions in rodents: Neural and neurochemical substrates. Neurosci Biobehav Rev 28: 771-784.

Dayas CV, Liu X, Simms JA, Weiss F. 2007. Distinct patterns of neural activation associated with ethanol seeking: effects of naltrexone. Biol Psychiatry 61: 979-989.

Deroche-Gamonet V, Belin D, Piazza PV. 2004. Evidence for addiction-like behavior in the rat. Science 305: 1014 1017. 
de Wit H, Stewart J. 1981. Reinstatement of cocaine-reinforced responding in the rat. Psychopharmacology 75: 134-143.

Di Chiara G. 1999. Drug addiction as dopamine-dependent associative learning disorder. Eur J Pharmacol 375: 1330.

Di Chiara G. 2002. Nucleus accumbens shell and core dopamine: Differential role in behavior and addiction. Behav Brain Res 137: 75-114.

Di Chiara G, Imperato A. 1988. Drugs abused by humans preferentially increase synaptic dopamine concentrations in the mesolimbic system of freely moving rats. Proc Nat Acad Sci 85: 5274-5278.

Di Ciano P, Everitt BJ. 2001. Dissociable effects of antagonism of NMDA and AMPA/KA receptors in the nucleus accumbens core and shell on cocaine-seeking behavior Neuropsychopharmacology 25: 341-360.

Di Ciano P, Everitt BJ. 2004a. Contribution of the ventral tegmental area to cocaine-seeking maintained by a drugpaired conditioned stimulus in rats. Eur J Neurosci 19: 1661-1667.

Di Ciano P, Everitt BJ. 2004b. Direct interactions between the basolateral amygdala and nucleus accumbens core underlie cocaine-seeking behavior in rats. J Neurosci 24: 7167-7173.

Di Ciano P, Coury A, Depoortere RY, Egilmez Y, Lane JD, Emmett-Oglesby MW, Lepiane FG, Phillips AG, Blaha CD. 1995. Comparison of changes in extracellular dopamine concentrations in the nucleus accumbens during intravenous self-administration of cocaine or d-amphetamine. Behav Pharmacol 6: 311-322.

Di Ciano P, Robbins TW, Everitt BJ. 2008. Differential effects of nucleus accumbens core, shell, or dorsal striatal inactivations on the persistence, reacquisition, or reinstatement of responding for a drug-paired conditioned reinforcer. Neuropsychopharmacology 33: 1413-1425.

Di Pietro NC, Black YD, Kantak KM. 2006. Context-dependent prefrontal cortex regulation of cocaine self-administration and reinstatement behaviors in rats. Eur J Neurosci 24: 3285-3298.

Dworkin SI, Guerin GF, Co C, Goeders NE, Smith JE. 1988a Lack of an effect of 6-hydroxydopamine lesions of the nucleus accumbens on intravenous morphine self-administration. Pharmacol Biochem Behav 30: 1051-1057.

Dworkin SI, Guerin GF, Goeders NE, Smith JE. 1988b. Kainic acid lesions of the nucleus accumbens selectively attenuate morphine self-administration. Pharmacol Biochem Behav 29: 175-181.

Erb S, Stewart J. 1999. A role for the bed nucleus of the stria terminalis, but not the amygdala, in the effects of corticotropin-releasing factor on stress-induced reinstatement of cocaine seeking. J Neurosci 19: RC35.

Erb S, Shaham Y, Stewart J. 1996. Stress reinstates cocaineseeking behavior after prolonged extinction and a drugfree period. Psychopharmacology 128: 408-412.

Erb S, Shaham Y, Stewart J. 1998. The role of corticotropinreleasing factor and corticosterone in stress- and cocaineinduced relapse to cocaine seeking in rats. J Neurosci 18: 5529-5536.

Erb S, Hitchcott PK, Rajabi H, Mueller D, Shaham Y, Stewart J. 2000. $\alpha$-2 Adrenergic receptor agonists block stress-induced reinstatement of cocaine seeking. Neuropsychopharmacology 23: 138-150.

Erb S, Salmaso N, Rodaros D, Stewart J. 2001. A role for the CRF-containing pathway from central nucleus of the amygdala to bed nucleus of the stria terminalis in the stress-induced reinstatement of cocaine seeking in rats. Psychopharmacology 158: 360-365.

Ersche KD, Barnes A, Jones PS, Morein-Zamir S, Robbins TW, Bullmore ET. 2011. Abnormal structure of frontostriatal brain systems is associated with aspects of impulsivity and compulsivity in cocaine dependence. Brain 134: 2013-2024.

Ettenberg A, Pettit HO, Bloom FE, Koob GF. 1982. Heroin and cocaine intravenous self-administration in rats: $\mathrm{Me}-$ diation by separate neural systems. Psychopharmacology 78: 204-209.

Everitt BJ, Robbins TW. 2005. Neural systems of reinforcement for drug addiction: From actions to habits to compulsion. Nature Neurosci 8: 1481-1489.

Everitt BJ, Dickinson A, Robbins TW. 2001. The neuropsychological basis of addictive behaviour. Brain Res Brain Res Rev 36: 129-138.

Everitt BJ, Hutcheson DM, Ersche KD, Pelloux Y, Dalley JW, Robbins TW. 2007. The orbital prefrontal cortex and drug addiction in laboratory animals and humans. Ann NY Acad Sci 1121: 576-597.

Everitt BJ, Belin D, Economidou D, Pelloux Y, Dalley JW, Robbins TW. 2008. Review. Neural mechanisms underlying the vulnerability to develop compulsive drug-seeking habits and addiction. Philos Trans R Soc Lond B Biol Sci 363: 3125-3135.

Fadda P, Scherma M, Spano MS, Salis P, Melis V, Fattore L, Fratta W. 2006. Cannabinoid self-administration increases dopamine release in the nucleus accumbens. Neuroreport 17: 1629-1632.

Feltenstein MW, See RE. 2007. NMDA receptor blockade in the basolateral amygdala disrupts consolidation of stimulus-reward memory and extinction learning during reinstatement of cocaine-seeking in an animal model of relapse. Neurobiol Learn Mem 88: 435-444.

Franklin TR, Druhan JP. 2000. Expression of Fos-related antigens in the nucleus accumbens and associated regions following exposure to a cocaine-paired environment. Eur J Neurosci 12: 2097-2106.

Franklin TR, Acton PD, Maldjian JA, Gray JD, Croft JR, Dackis CA, O’Brien CP, Childress AR. 2002. Decreased gray matter concentration in the insular, orbitofrontal, cingulate, and temporal cortices of cocaine patients. Biol Psychiatry 51: 134-142.

Fuchs RA, See RE. 2002. Basolateral amygdala inactivation abolishes conditioned stimulus- and heroin-induced reinstatement of extinguished heroin-seeking behavior in rats. Psychopharmacology 160: 425-433.

Fuchs RA, Evans KA, Parker MC, See RE. 2004a. Differential involvement of the core and shell subregions of the nucleus accumbens in conditioned cue-induced reinstatement of cocaine seeking in rats. Psychopharmacology 176: 459-465.

Fuchs RA, Evans KA, Parker MP, See RE. 2004b. Differential involvement of orbitofrontal cortex subregions in conditioned cue-induced and cocaine-primed reinstatement of cocaine seeking in rats. J Neurosci 24: 6600-6610. 
M.W. Feltenstein and R.E. See

Fuchs RA, Evans KA, Ledford CC, Parker MP, Case JM, Mehta RH, See RE. 2005. The role of the dorsomedial prefrontal cortex, basolateral amygdala, and dorsal hippocampus in contextual reinstatement of cocaine seeking in rats. Neuropsychopharmacology 30: 296-309.

Fuchs RA, Branham RK, See RE. 2006a. Different neural substrates mediate cocaine seeking after abstinence versus extinction training: A critical role for the dorsolateral caudate-putamen. J Neurosci 26: 3584-3588.

Fuchs RA, Feltenstein MW, See RE. 2006b. The role of the basolateral amygdala in stimulus-reward memory and extinction memory consolidation and in subsequent conditioned cued reinstatement of cocaine seeking. Eur J Neurosci 23: 2809-2813.

Fuchs RA, Eaddy JL, Su Z-I, Bell GH. 2007. Interactions of the basolateral amygdala with the dorsal hippocampus and dorseomedial prefrontal cortex regulate drug context-induced reinstatement of cocaine-seeking in rats. Eur J Neurosci 26: 487-498.

Fuchs RA, Bell GH, Ramirez DR, Eaddy JL, Su ZI. 2009. Basolateral amygdala involvement in memory reconsolidation processes that facilitate drug context-induced cocaine seeking. Eur J Neurosci 30: 889-900.

Gabriele A, See RE. 2010. Reversible inactivation of the basolateral amygdala, but not the dorsolateral caudate putamen, attenuates consolidation of cocaine-cue associative learning in a reinstatement model of drug-seeking. Eur J Neurosci 32: 1024-1029.

Gabriele A, See RE. 2011. Lesions and reversible inactivation of the dorsolateral caudate-putamen impair cocaineprimed reinstatement to cocaine-seeking in rats. Brain Res 1417: 27-35.

Gallagher M, McMahan RW, Schoenbaum G. 1999. Orbitofrontal cortex and representation of incentive value in associative learning. J Neurosci 19: 6610-6614.

Gatto GJ, McBride WJ, Murphy JM, Lumeng L, Li TK. 1994. Ethanol self-infusion into the ventral tegmental area by alcohol-preferring rats. Alcohol 11: 557-564.

Gerrits MA, Ramsey NF, Wolterink G, van Ree JM. 1994. Lack of evidence for an involvement of nucleus accumbens dopamine D1 receptors in the initiation of heroin self-administration in the rat. Psychopharmacology 114: 486-494.

Goldstein RZ, Volkow ND. 2002. Drug addiction and its underlying neurobiological basis: Neuroimaging evidence for the involvement of the frontal cortex. Am J Psychiatry 159: 1642-1652.

Grant S, London ED, Newlin DB, Villemagne VL, Liu X, Contoreggi C, Phillips RL, Kimes AS, Margolin A. 1996. Activation of memory circuits during cue-elicited cocaine craving. Proc Natl Acad Sci 93: 12040-12045.

Grimm JW, See RE. 2000. Dissociation of primary and secondary reward-relevant limbic nuclei in an animal model of relapse. Neuropsychopharmacology 22: 473-479.

Haber SN, Fudge JL, McFarland NR. 2000. Striatonigrostriatal pathways in primates form an ascending spiral from the shell to the dorsolateral striatum. J Neurosci 20: $2369-2382$.

Harris GC, Wimmer M, Aston-Jones G. 2005. A role for lateral hypothalamic orexin neurons in reward seeking. Nature 437: 556-559.
Hemby SE, Martin TJ, Co C, Dworkin SI, Smith JE. 1995. The effects of intravenous heroin administration on extracellular nucleus accumbens dopamine concentrations as determined by in vivo microdialysis. J Pharmacol Exp Ther 273: 591-598.

Hester R, Garavan H. 2004. Executive dysfunction in cocaine addiction: Evidence for discordant frontal, cingulate, and cerebellar activity. J Neurosci 24: 11017-11022.

Higgins RL, Marlatt GA. 1975. Fear of interpersonal evaluation as a determinant of alcohol consumption in male social drinkers. J Abnorm Psychol 84: 644-651.

Highfield D, Yap J, Grimm JW, Shalev U, Shaham Y. 2001. Repeated lofexidine treatment attenuates stress-induced, but not drug cues-induced reinstatement of a heroincocaine mixture (speedball) seeking in rats. Neuropsychopharmacology 25: 320-331.

Hiranita T, Nawata Y, Sakimura K, Anggadiredja K, Yamamoto T. 2006. Suppression of methamphetamineseeking behavior by nicotinic agonists. Proc Natl Acad Sci 103: 8523-8527.

Hoebel BG, Monaco AP, Hernandez L, Aulisi EF, Stanley BG, Lenard L. 1983. Self-injection of amphetamine directly into the brain. Psychopharmacology 81: 158-163.

Hungund BL, Szakall I, Adam A, Basavarajappa BS, Vadasz C. 2003. Cannabinoid CB1 receptor knockout mice exhibit markedly reduced voluntary alcohol consumption and lack alcohol-induced dopamine release in the nucleus accumbens. J Neurochem 84: 698-704.

Hurd YL, Weiss F, Koob GF, And NE, Ungerstedt U. 1989. Cocaine reinforcement and extracellular dopamine overflow in rat nucleus accumbens: An in vivo microdialysis study. Brain Res 498: 199-203.

Hyman SE, Malenka RC. 2001. Addiction and the brain: The neurobiology of compulsion and its persistence. Nat Rev 2: 695-703.

Ikemoto S. 2007. Dopamine reward circuitry: Two projection systems from the ventral midbrain to the nucleus accumbens-olfactory tubercle complex. Brain Res Rev 56: $27-78$.

Ito R, Dalley JW, Howes SR, Robbins TW, Everitt BJ. 2000. Dissociation in conditioned dopamine release in the nucleus accumbens core and shell in response to cocaine cues and during cocaine-seeking behavior in rats. J Neurosci 20: 7489-7495.

Ito R, Dalley JW, Robbins TW, Everitt BJ. 2002. Dopamine release in the dorsal striatum during cocaine-seeking behavior under the control of a drug-associated cue. J Neurosci 22: 6247-6253.

Izquierdo A, Belcher AM, Scott L, Cazares VA, Chen J, O’Dell SJ, Malvaez M, Wu T, Marshall JF. 2010. Reversal-specific learning impairments after a binge regimen of methamphetamine in rats: Possible involvement of striatal dopamine. Neuropsychopharmacology 35: 505-514.

Jaffe JH, Cascella NG, Kumor KM, Sherer MA. 1989. Cocaine-induced cocaine craving. Psychopharmacology 97: 59-64.

Jalabert M, Bourdy R, Courtin J, Veinante P, Manzoni OJ, Barrot M, Georges F. 2011. Neuronal circuits underlying acute morphine action on dopamine neurons. Proc Natl Acad Sci 108: $16446-16450$. 
Jentsch JD, Taylor JR. 1999. Impulsivity resulting from frontostriatal dysfunction in drug abuse: Implications for the control of behavior by reward-related stimuli. Psychopharmacology 146: 373-390.

Jhou TC, Fields HL, Baxter MG, Saper CB, Holland PC. 2009. The rostromedial tegmental nucleus (RMTg), a GABAergic afferent to midbrain dopamine neurons, encodes aversive stimuli and inhibits motor responses. $\mathrm{Neu}$ ron 61: 786-800.

Jog MS, Kubota Y, Connolly CI, Hillegaart V, Graybiel AM. 1999. Building neural representations of habits. Science 286: $1745-1749$.

Johnson SW, North RA. 1992. Opioids excite dopamine neurons by hyperpolarization of local interneurons. J Neurosci 12: 483-488.

Kalivas PW, McFarland K. 2003. Brain circuitry and the reinstatement of cocaine-seeking behavior. Psychopharmacology 168: 44-56.

Kalivas PW, Volkow ND. 2005. The neural basis of addiction: A pathology of motivation and choice. Am J Psychiatry 162: 1403-1413.

Kaufling J, Veinante P, Pawlowski SA, Freund-Mercier MJ, Barrot M. 2009. Afferents to the GABAergic tail of the ventral tegmental area in the rat. J Comp Neurol 513: 597-621.

Kaufman JN, Ross TJ, Stein EA, Garavan H. 2003. Cingulate hypoactivity in cocaine users during a GO-NOGO task as revealed by event-related functional magnetic resonance imaging. J Neurosci 23: 7839-7843.

Kilts CD, Schweitzer JB, Quinn CK, Gross RE, Faber TL, Muhammad F, Ely TD, Hoffman JM, Drexler KP. 2001 Neural activity related to drug craving in cocaine addiction. Arch Gen Psychiatry 58: 334-341.

Kilts CD, Gross RE, Ely TD, Drexler KP. 2004. The neural correlates of cue-induced craving in cocaine-dependent women. Am J Psychiatry 161: 233-241.

Kolb B, Pellis S, Robinson TE. 2004. Plasticity and functions of the orbital frontal cortex. Brain Cogn 55: 104-115.

Koob GF. 1992. Drugs of abuse: Anatomy, pharmacology and function of reward pathways. Trends Pharmacol Sci 13: $177-184$.

Koob GF. 2004. Allostatic view of motivation: Implications for psychopathology. Nebr Symp Motiv 50: 1-18.

Koob GF, Bloom FE. 1988. Cellular and molecular mechanisms of drug dependence. Science 242: 715-723.

Koob GF, Le Moal M. 1997. Drug abuse: Hedonic homeostatic dysregulation. Science 278: 52-58.

Koob GF, Le Moal M. 2001. Drug addiction, dysregulation of reward, and allostasis. Neuropsychopharmacology 24: 97-129.

Koob GF, Le Moal M. 2006. Neurobiology of addiction. Academic, London.

Koob GF, Volkow ND. 2010. Neurocircuitry of addiction. Neuropsychopharmacology 35: 217-238.

Kornetsky C, Bain G. 1990. Brain-stimulation reward: A model for drug induced euphoria. In Testing and evaluation of drugs of abuse (ed. Adler MW, Cowan A), pp. 211-231. Wiley-Liss, New York.

Kornetsky C, Esposito RU, McLean S, Jacobson JO. 1979. Intracranial self-stimulation thresholds: A model for the hedonic effects of drugs of abuse. Arch Gen Psychiatry 36: 289-292.

Koya E, Spijker S, Voorn P, Binnekade R, Schmidt ED, Schoffelmeer AN, De Vries TJ, Smit AB. 2006. Enhanced cortical and accumbal molecular reactivity associated with conditioned heroin, but not sucrose-seeking behaviour. J Neurochem 98: 905-915.

Kruzich PJ, See RE. 2001. Differential contributions of the basolateral and central amygdala in the acquisition and expression of conditioned relapse to cocaine-seeking behavior. J Neurosci 21: RC155.

Kufahl PR, Zavala AR, Singh A, Thiel KJ, Dickey ED, Joyce JN, Neisewander JL. 2009. c-Fos expression associated with reinstatement of cocaine-seeking behavior by responsecontingent conditioned cues. Synapse 63: 823-835.

LaLumiere RT, Kalivas PW. 2008. Glutamate release in the nucleus accumbens core is necessary for heroin seeking. J Neurosci 28: 3170-3177.

Lanca AJ, Adamson KL, Coen KM, Chow BL, Corrigall WA. 2000. The pedunculopontine tegmental nucleus and the role of cholinergic neurons in nicotine self-administration in the rat: A correlative neuroanatomical and behavioral study. Neuroscience 96: 735-742.

Lasseter HC, Ramirez DR, Xie X, Fuchs RA. 2009. Involvement of the lateral orbitofrontal cortex in drug contextinduced reinstatement of cocaine-seeking behavior in rats. Eur J Neurosci 30: 1370-1381.

Lasseter HC, Xie X, Ramirez DR, Fuchs RA. 2010a. Prefrontal cortical regulation of drug seeking in animal models of drug relapse. Curr Top Behav Neurosci 3: 101-117.

Lasseter HC, Xie X, Ramirez DR, Fuchs RA. 2010b. Subregion specific contribution of the ventral hippocampus to drug context-induced reinstatement of cocaine-seeking behavior in rats. Neuroscience 171: 830-839.

Lasseter HC, Wells AM, Xie X, Fuchs RA. 2011. Interaction of the basolateral amygdala and orbitofrontal cortex is critical for drug context-induced reinstatement of cocaine-seeking behavior in rats. Neuropsychopharmacology 36: 711-720.

Lavezzi HN, Zahm DS. 2011. The mesopontine rostromedial tegmental nucleus: An integrative modulator of the reward system. Basal Ganglia 1: 191-200.

Lawrence AJ, Cowen MS, Yang HJ, Chen F, Oldfield B. 2006 The orexin system regulates alcohol-seeking in rats. $\mathrm{Br}$ Pharmacol 148: 752-759.

Le AD, Harding S, Juzytsch W, Watchus J, Shalev U, Shaham Y. 2000. The role of corticotrophin-releasing factor in stress-induced relapse to alcohol-seeking behavior in rats. Psychopharmacology 150: 317-324.

Le AD, Harding S, Juzytsch W, Funk D, Shaham Y. 2005. Role of $\alpha-2$ adrenoceptors in stress-induced reinstatement of alcohol seeking and alcohol self-administration in rats. Psychopharmacology 179: 366-373.

Lecca D, Cacciapaglia F, Valentini V, Di Chiara G. 2006a. Monitoring extracellular dopamine in the rat nucleus accumbens shell and core during acquisition and maintenance of intravenous WIN 55,212-2 self-administration. Psychopharmacology 188: 63-74.

Lecca D, Cacciapaglia F, Valentini V, Gronli J, Spiga S, Di Chiara G. 2006b. Preferential increase of extracellular dopamine in the rat nucleus accumbens shell as 
M.W. Feltenstein and R.E. See

compared to that in the core during acquisition and maintenance of intravenous nicotine self-administration. Psychopharmacology 184: 435-446.

Lecca S, Melis M, Luchicchi A, Ennas MG, Castelli MP, Muntoni AL, Pistis M. 2011. Effects of drugs of abuse on putative rostromedial tegmental neurons, inhibitory afferents to midbrain dopamine cells. Neuropsychopharmacology 36: 589-602.

Ledent C, Valverde O, Cossu G, Petitet F, Aubert JF, Beslot F, Bohme GA, Imperato A, Pedrazzini T, Roques BP, et al. 1999. Unresponsiveness to cannabinoids and reduced addictive effects of opiates in CB1 receptor knockout mice. Science 283: 401-404.

Lee B, Tiefenbacher S, Platt DM, Spealman RD. 2004. Pharmacological blockade of alpha2-adrenoceptors induces reinstatement of cocaine-seeking behavior in squirrel monkeys. Neuropsychopharmacology 29: 686-693.

Leri F, Flores J, Rodaros D, Stewart J. 2002. Blockade of stress-induced but not cocaine-induced reinstatement by infusion of noradrenergic antagonists into the bed nucleus of the stria terminalis or the central nucleus of the amygdala. J Neurosci 22: 5713-5718.

Letchworth SR, Nader MA, Smith HR, Friedman DP, Porrino LJ. 2001. Progression of changes in dopamine transporter binding site density as a result of cocaine self-administration in rhesus monkeys. J Neurosci 21: 2799-2807.

London ED, Bonson KR, Ernst M, Grant S. 1999. Brain imaging studies of cocaine abuse: Implications for medication development. Crit Rev Neurobiol 13: 227-242.

Lucantonio F, Stalnaker TA, Shaham Y, Niv Y, Schoenbaum G. 2012. The impact of orbitofrontal dysfunction on cocaine addiction. Nature Neurosci 15: 358-366.

Lyness WH, Smith FL. 1992. Influence of dopaminergic and serotonergic neurons on intravenous ethanol self-administration in the rat. Pharmacol Biochem Behav 42: 187-192.

Lyness WH, Friedle NM, Moore KE. 1979. Destruction of dopaminergic nerve terminals in nucleus accumbens: Effect on d-amphetamine self-administration. Pharmacol Biochem Behav 11: 553-556.

Maas LC, Lukas SE, Kaufman MJ, Weiss RD, Daniels SL, Rogers VW, Kukes TJ, Renshaw PF. 1998. Functional magnetic resonance imaging of human brain activation during cue-induced cocaine craving. Am J Psychiatry 155: $124-126$.

Mark GP, Shabani S, Dobbs LK, Hansen ST. 2011. Cholinergic modulation of mesolimbic dopamine function and reward. Physiol Behav 104: 76-81.

Maskos U. 2008. The cholinergic mesopontine tegmentum is a relatively neglected nicotinic master modulator of the dopaminergic system: Relevance to drugs of abuse and pathology. Br J Pharmacol 153: S438-S445.

Matochik JA, London ED, Eldreth DA, Cadet JL, Bolla KI 2003. Frontal cortical tissue composition in abstinent cocaine abusers: A magnetic resonance imaging study. Neuroimage 19: 1095-1102.

McFarland K, Kalivas PW. 2001. The circuitry mediating cocaine-induced reinstatement of drug-seeking behavior. J Neurosci 21: 8655-8663.

McFarland K, Lapish CC, Kalivas PW. 2003. Prefrontal glutamate release into the core of the nucleus accumbens mediates cocaine-induced reinstatement of drug-seeking behavior. J Neurosci 23: 3531-3537.

McFarland K, Davidge SB, Lapish CC, Kalivas PW. 2004. Limbic and motor circuitry underlying footshock-induced reinstatement of cocaine-seeking behavior. J Neurosci 24: $1551-1560$.

McGregor IS, Bowen MT. 2012. Breaking the loop: Oxytocin as a potential treatment for drug addiction. Horm Behav 61: 331-339.

McLaughlin J, See RE. 2003. Selective inactivation of the dorsomedial prefrontal cortex and the basolateral amygdala attenuates conditioned-cued reinstatement of extinguished cocaine-seeking behavior in rats. Psychopharmacology 168: 57-65.

Meil WM, See RE. 1997. Lesions of the basolateral amygdala abolish the ability of drug associated cues to reinstate responding during withdrawal from self-administered cocaine. Behav Brain Res 87: 139-148.

Meil WM, Roll JM, Grimm JW, Lynch AM, See RE. 1995. Tolerance-like attenuation to contingent and noncontingent cocaine- induced elevation of extracellular dopamine in the ventral striatum following 7 days of withdrawal from chronic treatment. Psychopharmacology 118: $338-346$.

Melendez RI, Rodd-Henricks ZA, Engleman EA, Li TK, McBride WJ, Murphy JM. 2002. Microdialysis of dopamine in the nucleus accumbens of alcohol-preferring $(\mathrm{P})$ rats during anticipation and operant self-administration of ethanol. Alcohol Clin Exp Res 26: 318-325.

Meyer RE. 1996. The disease called addiction: Emerging evidence of a 200-year debate. Lancet 347: 162-166.

Meyers RA, Zavala AR, Speer CM, Neisewander JL. 2006. Dorsal hippocampus inhibition disrupts acquisition and expression, but not consolidation, of cocaine conditioned place preference. Behav Neurosci 120: 401-412.

Monaco AP, Hernandez L, Hoebel BG. 1981. Nucleus accumbens: Site of amphetamine self-administration. Comparison with the lateral ventricle. In Neurobiology of the nucleus accumbens (ed. Chronister RB, DeFrance JF), pp. 338-343. Haer Institute, Brunswick, ME.

Myers RD. 1974. Handbook of drug and chemical stimulation of the brain. Van Nostrand Reinhold, New York.

Nader MA, Daunais JB, Moore T, Nader SH, Moore RJ, Smith HR, Friedman DP, Porrino LJ. 2002. Effects of cocaine self-administration on striatal dopamine systems in rhesus monkeys: Initial and chronic exposure. Neuropsychopharmacology 27: 35-46.

Neisewander JL, Baker DA, Fuchs RA, Tran-Nguyen LT, Palmer A, Marshall JF. 2000. Fos protein expression and cocaine-seeking behavior in rats after exposure to a cocaine self-administration environment. J Neurosci 20: 798-805.

Nesse RM, Berridge KC. 1997. Psychoactive drug use in evolutionary perspective. Science 278: 63-66.

Nestler EJ. 2005. Is there a common molecular pathway for addiction? Nature Neurosci 8: 1445-1449.

Olausson P, Jentsch JD, Krueger DD, Tronson NC, Nairn AC, Taylor JR. 2007. Orbitofrontal cortex and cognitive-motivational impairments in psychostimulant addiction: Evidence from experiments in the non-human primate. Ann NY Acad Sci 1121: 610-638. 
Olds ME. 1982. Reinforcing effects of morphine in the nucleus accumbens. Brain Res 237: 429-440.

Olds J, Milner P. 1954. Positive reinforcement produced by electrical stimulation of septal area and other regions of rat brain. J Comp Physiol Psychol 47: 419-427.

Park WK, Bari WW, Jey AR, Anderson SM, Spealman RD, Rowlett JK, Pierce RC. 2002. Cocaine administered into the medial prefrontal cortex reinstates cocaine-seeking behavior by increasing AMPA receptor-mediated glutamate transmission in the nucleus accumbens. J Neurosci 22: 2916-2925.

Parsegian A, Glen WB Jr, Lavin A, See RE. 2011. Methamphetamine self-administration produces attentional setshifting deficits and alters prefrontal cortical neurophysiology in rats. Biol Psychiatry 69: 253-259.

Peters J, LaLumiere RT, Kalivas PW. 2008. Infralimbic prefrontal cortex is responsible for inhibiting cocaine seeking in extinguished rats. J Neurosci 28: 6046-6053.

Pettit HO, Justice JB Jr. 1989. Dopamine in the nucleus accumbens during cocaine self-administration as studied by in vivo microdialysis. Pharmacol Biochem Behav 34: 899-904.

Pettit HO, Ettenberg A, Bloom FE, Koob GF. 1984. Destruction of dopamine in the nucleus accumbens selectively attenuates cocaine but not heroin self-administration in rats. Psychopharmacology 84: 167-173.

Pickens R, Meisch RA, Dougherty JA Jr. 1968. Chemical interactions in methamphetamine reinforcement. Psychol Rep 23: 1267-1270.

Plaza-Zabala A, Martin-Garcia E, de Lecea L, Maldonado R, Berrendero F. 2010. Hypocretins regulate the anxiogeniclike effects of nicotine and induce reinstatement of nicotine-seeking behavior. J Neurosci 30: 2300-2310.

Pontieri FE, Tanda G, Di Chiara G. 1995. Intravenous cocaine, morphine, and amphetamine preferentially increase extracellular dopamine in the "shell" as compared with the "core" of the rat nucleus accumbens. Proc Natl Acad Sci 92: 12304-12308.

Pontieri FE, Tanda G, Orzi F, Di Chiara G. 1996. Effects of nicotine on the nucleus accumbens and similarity to those of addictive drugs. Nature 382: 255-257.

Porrino LJ, Lyons D, Smith HR, Daunais JB, Nader MA. 2004. Cocaine self-administration produces a progressive involvement of limbic, association, and sensorimotor striatal domains. J Neurosci 24: 3554-3562.

Porter JN, Olsen AS, Gurnsey K, Dugan BP, Jedema HP, Bradberry CW. 2011. Chronic cocaine self-administration in rhesus monkeys: Impact on associative learning, cognitive control, and working memory. J Neurosci 31: 4926-4934.

Ramirez DR, Bell GH, Lasseter HC, Xie X, Traina SA, Fuchs RA. 2009. Dorsal hippocampal regulation of memory reconsolidation processes that facilitate drug contextinduced cocaine-seeking behavior in rats. Eur J Neurosc 30: 901-912.

Rassnick S, Pulvirenti L, Koob GF. 1992. Oral ethanol selfadministration in rats is reduced by the administration of dopamine and glutamate receptor antagonists into the nucleus accumbens. Psychopharmacology 109: 92-98.

Rassnick S, Stinus L, Koob GF. 1993. The effects of 6-hydroxydopamine lesions of the nucleus accumbens and the mesolimbic dopamine system on oral self-administration of ethanol in the rat. Brain Res 623: 16-24.

Richards JK, Simms JA, Steensland P, Taha SA, Borgland SL, Bonci A, Bartlett SE. 2008. Inhibition of orexin-1/hypocretin-1 receptors inhibits yohimbine-induced reinstatement of ethanol and sucrose seeking in Long-Evans rats. Psychopharmacology 199: 109-117.

Richardson NR, Smith AM, Roberts DC. 1994. A single injection of either flupenthixol decanoate or haloperidol decanoate poroduces long-term changes in cocaine selfadministration in rats. Alcohol Drug Depend 36: 23-25.

Robbins TW, Everitt BJ. 1996. Neurobehavioural mechanisms of reward and motivation. Curr Opin Neurobiol 6: $228-236$.

Roberts DCS. 1992. Neural substrates mediating cocaine reinforcement: The role of monoamine systems. In $\mathrm{Co}$ caine: Pharmacology, physiology and clinical strategies (ed. Lakoski JM, Galloway MP, White FJ), pp. 73-90. CRC Press, Boca Raton, FL.

Roberts DC, Koob GF. 1982. Disruption of cocaine self-administration following 6-hydroxydopamine lesions of the ventral tegmental area in rats. Pharmacol Biochem Behav 17: $901-904$.

Roberts DC, Corcoran ME, Fibiger HC. 1977. On the role of ascending catecholaminergic systems in intravenous selfadministration of cocaine. Pharmacol Biochem Behav 6: 615-620.

Roberts DC, Koob GF, Klonoff P, Fibiger HC. 1980. Extinction and recovery of cocaine self-administration following 6-hydroxydopamine lesions of the nucleus accumbens. Pharmacol Biochem Behav 12: 781-787.

Robinson TE, Berridge KC. 1993. The neural basis of drug craving: An incentive-sensitization theory of addiction. Brain Res Brain Res Rev 18: 247-291.

Rodd ZA, Bell RL, Melendez RI, Kuc KA, Lumeng L, Li TK, Murphy JM, McBride WJ. 2004a. Comparison of intracranial self-administration of ethanol within the posterior ventral tegmental area between alcohol-preferring and Wistar rats. Alcohol Clin Exp Res 28: 1212-1219.

Rodd ZA, Melendez RI, Bell RL, Kuc KA, Zhang Y, Murphy JM, McBride WJ. 2004b. Intracranial self-administration of ethanol within the ventral tegmental area of male Wistar rats: Evidence for involvement of dopamine neurons. J Neurosci 24: 1050-1057.

Rodd ZA, Bell RL, Kuc KA, Zhang Y, Murphy JM, McBride WJ. 2005. Intracranial self-administration of cocaine within the posterior ventral tegmental area of Wistar rats: Evidence for involvement of serotonin-3 receptors and dopamine neurons. J Pharmacol Exp Ther 313: 134145.

Rodd-Henricks ZA, McKinzie DL, Li TK, Murphy JM, McBride WJ. 2002. Cocaine is self-administered into the shell but not the core of the nucleus accumbens of Wistar rats. J Pharmacol Exp Ther 303: 1216-1226.

Roesch MR, Takahashi Y, Gugsa N, Bissonette GB, Schoenbaum G. 2007. Previous cocaine exposure makes rats hypersensitive to both delay and reward magnitude. J Neurosci 27: 245-250.

Rogers JL, See RE. 2007. Selective inactivation of the ventral hippocampus attenuates cue-induced and cocaineprimed reinstatement of drug-seeking in rats. Neurobiol Learn Mem 87: 688-692. 
M.W. Feltenstein and R.E. See

Rogers RD, Everitt BJ, Baldacchino A, Blackshaw AJ, Swainson R, Wynne K, Baker NB, Hunter J, Carthy T, Booker E, et al. 1999. Dissociable deficits in the decision-making cognition of chronic amphetamine abusers, opiate abusers, patients with focal damage to prefrontal cortex, and tryptophan-depleted normal volunteers: Evidence for monoaminergic mechanisms. Neuropsychopharmacology 20: 322-339.

Rogers JL, Ghee S, See RE. 2008. The neural circuitry underlying reinstatement of heroin-seeking behavior in an animal model of relapse. Neuroscience 151: 579-588.

Russell JA, Mehrabian A. 1975. The mediating role of emotions in alcohol use. J Stud Alcohol 36: 1508-1536.

SAMHSA. 2011. Results from the 2010 National Survey on Drug Use and Health (NSDUH), NSDUH Series H-41, HHS Publication No. (SMA) 11-4658. SAMHS Administration, Rockville, MD.

Samson HH, Doyle TF. 1985. Oral ethanol self-administration in the rat: Effect of naloxone. Pharmacol Biochem Behav 22: 91-99.

Sanchez CJ, Bailie TM, Wu WR, Li N, Sorg BA. 2003. Manipulation of dopamine $\mathrm{d} 1$-like receptor activation in the rat medial prefrontal cortex alters stress- and cocaineinduced reinstatement of conditioned place preference behavior. Neuroscience 119: 497-505.

Sarnyai Z. 2011. Oxytocin as a potential mediator and modulator of drug addiction. Addict Biol 16: 199-201.

Schoenbaum G, Roesch MR, Stalnaker TA. 2006. Orbitofrontal cortex, decision-making and drug addiction. Trends Neurosci 29: 116-124.

See RE. 2005. Neural substrates of cocaine-cue associations that trigger relapse. Eur J Pharmacol 526: 140-146.

See RE, Kruzich PJ, Grimm JW. 2001. Dopamine, but not glutamate, receptor blockade in the basolateral amygdala attenuates conditioned reward in a rat model of relapse to cocaine-seeking behavior. Psychopharmacology 154: $301-310$.

See RE, McLaughlin J, Fuchs RA. 2003. Muscarinic receptor antagonism in the basolateral amygdala blocks acquisition of cocaine-stimulus association in a model of relapse to cocaine-seeking behavior in rats. Neuroscience 117: 477-483.

See RE, Elliott JC, Feltenstein MW. 2007. The role of dorsal vs ventral striatal pathways in cocaine-seeking behavior after prolonged abstinence in rats. Psychopharmacology 194: 321-331.

Shaham Y, Funk D, Erb S, Brown TJ, Walker CD, Stewart J. 1997. Corticotropin-releasing factor, but not corticosterone, is involved in stress-induced relapse to heroin-seeking in rats. J Neurosci 17: 2605-2614.

Shaham Y, Erb S, Stewart J. 2000a. Stress-induced relapse to heroin and cocaine seeking in rats: A review. Brain Res Brain Res Rev 33: 13-33.

Shaham Y, Highfield D, Delfs J, Leung S, Stewart J. 2000b. Clonidine blocks stress-induced reinstatement of heroin seeking in rats: An effect independent of locus coeruleus noradrenergic neurons. Eur J Neurosci 12: 292-302.

Shaham Y, Shalev U, Lu L, De Wit H, Stewart J. 2003. The reinstatement model of drug relapse: History, methodology and major findings. Psychopharmacology 168: 3-20.
Shepard JD, Bossert JM, Liu SY, Shaham Y. 2004. The anxiogenic drug yohimbine reinstates methamphetamine seeking in a rat model of drug relapse. Biol Psychiatry 55: $1082-1089$.

Shoblock JR, Welty N, Aluisio L, Fraser I, Motley ST, Morton K, Palmer J, Bonaventure P, Carruthers NI, Lovenberg TW, et al. 2011. Selective blockade of the orexin-2 receptor attenuates ethanol self-administration, place preference, and reinstatement. Psychopharmacology 215: 191-203.

Simon NW, Mendez IA, Setlow B. 2007. Cocaine exposure causes long-term increases in impulsive choice. Behav Neurosci 121: 543-549.

Sinha R, Catapano D, O'Malley S. 1999. Stress-induced craving and stress response in cocaine dependent individuals. Psychopharmacology 142: 343-351.

Smith RJ, Aston-Jones G. 2012. Orexin/hypocretin 1 receptor antagonist reduces heroin self-administration and cueinduced heroin seeking. Eur J Neurosci 35: 798-804.

Smith JE, Guerin GF, Co C, Barr TS, Lane JD. 1985. Effects of 6-OHDA lesions of the central medial nucleus accumbens on rat intravenous morphine self-administration. Pharmacol Biochem Behav 23: 843-849.

Smith RJ, See RE, Aston-Jones G. 2009. Orexin/hypocretin signaling at the orexin 1 receptor regulates cue-elicited cocaine-seeking. Eur J Neurosci 30: 493-503.

Smith RJ, Tahsili-Fahadan P, Aston-Jones G. 2010. Orexin/ hypocretin is necessary for context-driven cocaine-seeking. Neuropharmacology 58: 179-184.

Soria G, Mendizabal V, Tourino C, Robledo P, Ledent C, Parmentier M, Maldonado R, Valverde O. 2005. Lack of CB1 cannabinoid receptor impairs cocaine self-administration. Neuropsychopharmacology 30: 1670-1680.

Stewart J. 2000. Pathways to relapse: The neurobiology of drug- and stress-induced relapse to drug-taking. J Psychiatry Neurosci 25: 125-136.

Sun W, Rebec GV. 2005. The role of prefrontal cortex D1-like and D2-like receptors in cocaine-seeking behavior in rats. Psychopharmacology 177: 315-323.

Thanos PK, Dimitrakakis ES, Rice O, Gifford A, Volkow ND. 2005. Ethanol self-administration and ethanol conditioned place preference are reduced in mice lacking cannabinoid CB1 receptors. Behav Brain Res 164: 206-213.

Thompson PM, Hayashi KM, Simon SL, Geaga JA, Hong MS, Sui Y, Lee JY, Toga AW, Ling W, London ED. 2004. Structural abnormalities in the brains of human subjects who use methamphetamine. J Neurosci 24: 6028-6036.

Vanderschuren LJ, Everitt BJ. 2004. Drug seeking becomes compulsive after prolonged cocaine self-administration. Science 305: 1017-1019.

Vanderschuren LJ, Di Ciano P, Everitt BJ. 2005. Involvement of the dorsal striatum in cue-controlled cocaine seeking. $J$ Neurosci 25: 8665-8670.

van Erp AM, Miczek KA. 2007. Increased accumbal dopamine during daily alcohol consumption and subsequent aggressive behavior in rats. Psychopharmacology 191: 679-688.

van Ree JM, de Wied D. 1980. Involvement of neurohypophyseal peptides in drug-mediated adaptive responses. Pharmacol Biochem Behav 13: 257-263. 
van Ree JM, Gerrits MAFM, Vanderschuren LJMJ. 1999. Opioids, reward and addiction: An encounter of biology, psychology, and medicine. Pharmacol Rev 51: 341-396.

Volkow ND, Fowler JS. 2000. Addiction, a disease of compulsion and drive: Involvement of the orbitofrontal cortex. Cereb Cortex 10: 318-325.

Volkow ND, Fowler JS, Wang GJ, Hitzemann R, Logan J, Schlyer DJ, Dewey SL, Wolf AP. 1993. Decreased dopamine D2 receptor availability is associated with reduced frontal metabolism in cocaine abusers. Synapse 14: 169-177.

Volkow ND, Fowler JS, Wang GJ. 2003. The addicted human brain: Insights from imaging studies. J Clin Invest 111: 1444-1451.

Volkow ND, Wang GJ, Telang F, Fowler JS, Logan J, Childress AR, Jayne M, Ma Y, Wong C. 2006. Cocaine cues and dopamine in dorsal striatum: Mechanism of craving in cocaine addiction. J Neurosci 26: 6583-6588.

Wagner FA, Anthony JC. 2002. From first drug use to drug dependence; developmental periods of risk for dependence upon marijuana, cocaine, and alcohol. Neuropsychopharmacology 26: 479-488.

Weiss F, Hurd YL, Ungerstedt U, Markou A, Plotsky PM, Koob GF. 1992. Neurochemical correlates of cocaine and ethanol self-administration. Ann NY Acad Sci 654: 220 241.

Weiss F, Lorang MT, Bloom FE, Koob GF. 1993. Oral alcohol self-administration stimulates dopamine release in the rat nucleus accumbens: Genetic and motivational determinants. J Pharmacol Exp Ther 267: 250-258.

Weiss F, Maldonado-Vlaar CS, Parsons LH, Kerr TM, Smith DL, Ben-Shahar O. 2000. Control of cocaine-seeking behavior by drug-associated stimuli in rats: Effects on recovery of extinguished operant-responding and extracellular dopamine levels in amygdala and nucleus accumbens. Proc Natl Acad Sci 97: 4321-4326.

Weissenborn R, Robbins TW, Everitt BJ. 1997. Effects of medial prefrontal or anterior cingulate cortex lesions on responding for cocaine under fixed-ratio and second-order schedules of reinforcement in rats. Psychopharmacology 134: 242-257.

Wells AM, Lasseter HC, Xie X, Cowhey KE, Reittinger AM, Fuchs RA. 2011. Interaction between the basolateral amygdala and dorsal hippocampus is critical for cocaine memory reconsolidation and subsequent drug contextinduced cocaine-seeking behavior in rats. Learn Mem 18: 693-702.

Whitelaw RB, Markou A, Robbins TW, Everitt BJ. 1996. Excitotoxic lesions of the basolateral amygdala impair the acquisition of cocaine-seeking behaviour under a second-order schedule of reinforcement. Psychopharmacology 127: 213-224.

Wilker A. 1973. Dynamics of drug dependence: Implications of a conditioning theory for research and treatment. Archiv Gen Psychiatry 28: 611-616.

Wilson MC, Schuster CR. 1974. Aminergic influences on intravenous cocaine self-administration by Rhesus monkeys. Pharmacol Biochem Behav 2: 563-571.

Winstanley CA, LaPlant Q, Theobald DE, Green TA, Bachtell RK, Perrotti LI, DiLeone RJ, Russo SJ, Garth WJ,
Self DW, et al. 2007. $\Delta$ FosB induction in orbitofrontal cortex mediates tolerance to cocaine-induced cognitive dysfunction. J Neurosci 27: 10497-10507.

Wise RA. 1980. Action of drugs of abuse on brain reward systems. Pharmacol Biochem Behav 13: 213-223.

Wise RA. 2002. Brain reward circuitry: Insights from unsensed incentives. Neuron 36: 229-240.

Wise RA, Leone P, Rivest R, Leeb K. 1995a. Elevations of nucleus accumbens dopamine and DOPAC levels during intravenous heroin self-administration. Synapse 21: $140-148$.

Wise RA, Newton P, Leeb K, Burnette B, Pocock D, Justice JB. 1995b. Fluctuations in nucleus accumbens dopamine concentration during intravenous cocaine self-administration in rats. Psychopharmacology 120: 10-20.

Wolffgramm J, Heyne A. 1995. From controlled drug intake to loss of control: The irreversible development of drug addiction in the rat. Behav Brain Res 70: 77-94.

Wong DF, Kuwabara H, Schretlen DJ, Bonson KR, Zhou Y, Nandi A, Brasic JR, Kimes AS, Maris MA, Kumar A, et al. 2006. Increased occupancy of dopamine receptors in human striatum during cue-elicited cocaine craving. Neuropsychopharmacology 31: 2716-2727.

Woolverton WL. 1986. Effects of a D1 and a D2 dopamine antagonist on the self-administration of cocaine and piribedil by rhesus monkeys. Pharmacol Biochem Behav 24: 531-535.

Xie X, Ramirez DR, Lasseter HC, Fuchs RA. 2010. Effects of mGluR1 antagonism in the dorsal hippocampus on drug context-induced reinstatement of cocaine-seeking behavior in rats. Psychopharmacology 208: 1-11.

Yokel RA, Wise RA. 1975. Increased lever pressing for amphetamine after pimozide in rats: Implications for a dopamine theory of reward. Science 187: 547-549.

Zapata A, Minney VL, Shippenberg TS. 2010. Shift from goal-directed to habitual cocaine seeking after prolonged experience in rats. J Neurosci 30: 15457-15463.

Zavala AR, Weber SM, Rice HJ, Alleweireldt AT, Neisewander JL. 2003. Role of the prelimbic subregion of the medial prefrontal cortex in acquisition, extinction, and reinstatement of cocaine-conditioned place preference. Brain Res 990: 157-164.

Zavala AR, Osredkar T, Joyce JN, Neisewander JL. 2008. Upregulation of Arc mRNA expression in the prefrontal cortex following cue-induced reinstatement of extinguished cocaine-seeking behavior. Synapse 62: 421-431.

Zhou W, Liu H, Zhang F, Tang S, Zhu H, Lai M, Kalivas PW. 2007. Role of acetylcholine transmission in nucleus accumbens and ventral tegmental area in heroin-seeking induced by conditioned cues. Neuroscience 144: 12091218.

Zhou L, Ghee SM, Chan C, Lin L, Cameron MD, Kenny PJ, See RE. 2012. Orexin-1 receptor mediation of cocaine seeking in male and female rats. J Pharmacol Exp Ther 340: $801-809$.

Zito KA, Vickers G, Roberts DC. 1985. Disruption of cocaine and heroin self-administration following kainic acid lesions of the nucleus accumbens. Pharmacol Biochem Behav 23: 1029-1036. 


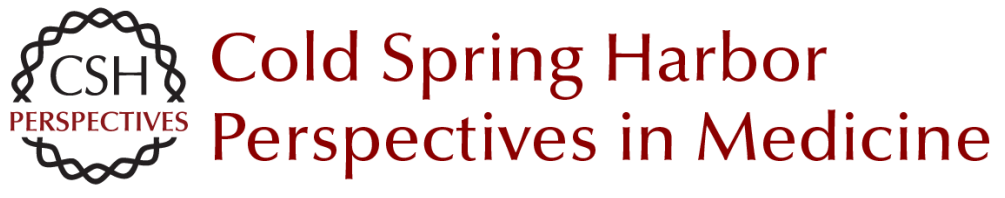

\section{Systems Level Neuroplasticity in Drug Addiction}

Matthew W. Feltenstein and Ronald E. See

Cold Spring Harb Perspect Med 2013; doi: 10.1101/cshperspect.a011916 originally published online April 11,2013

\section{Subject Collection Addiction}

Developments from Bulk Optogenetics to Single-Cell Strategies to Dissect the Neural Circuits that Underlie Aberrant Motivational States Jose Rodriguez-Romaguera, Vijay M.K. Namboodiri, Marcus L. Basiri, et al.

Consequences of Parental Opioid Exposure on Neurophysiology, Behavior, and Health in the Next Generations

Fair M. Vassoler and Mathieu E. Wimmer

Animal Models of the Behavioral Symptoms of Substance Use Disorders Louk J.M.J. Vanderschuren and Serge H. Ahmed

Translational Research in Nicotine Addiction Miranda L. Fisher, James R. Pauly, Brett Froeliger, et al.

Neonatal Opioid Withdrawal Syndrome (NOWS): A Transgenerational Echo of the Opioid Crisis Andrew E. Weller, Richard C. Crist, Benjamin C. Reiner, et al.

Impairment of Synaptic Plasticity by Cannabis, $\Delta^{\mathbf{9}}$ -THC, and Synthetic Cannabinoids Alexander F. Hoffman, Eun-Kyung Hwang and Carl R. Lupica

Drug-Evoked Synaptic Plasticity of Excitatory Transmission in the Ventral Tegmental Area Camilla Bellone, Michael Loureiro and Christian Lüscher

Opioid-Induced Molecular and Cellular Plasticity of Ventral Tegmental Area Dopamine Neurons Marie A. Doyle and Michelle S. Mazei-Robison
The Persistent Challenge of Developing Addiction Pharmacotherapies

Sarah E. Swinford-Jackson, Charles P. O'Brien,

Paul J. Kenny, et al.

Opioid Modulation of the Gut-Brain Axis in Opioid-Associated Comorbidities

Li Zhang and Sabita Roy

Epigenetics of Drug Addiction Andrew F. Stewart, Sasha L. Fulton and lan Maze

Genetic Vulnerability to Opioid Addiction Brian Reed and Mary Jeanne Kreek

Glutamatergic Systems and Memory Mechanisms

Underlying Opioid Addiction Jasper A. Heinsbroek, Taco J. De Vries and Jamie Peters

Mechanisms of Nicotine Addiction Marina R. Picciotto and Paul J. Kenny

Neural Substrates and Circuits of Drug Addiction Matthew W. Feltenstein, Ronald E. See and Rita A. Fuchs

The Role of the Central Amygdala in Alcohol Dependence Marisa Roberto, Dean Kirson and Sophia Khom

For additional articles in this collection, see http://perspectivesinmedicine.cshlp.org/cgi/collection/ 